\title{
A ética marxista: aproximações conceituais, perspectivas políticas e educacionais
}

Antonio Carlos Souza ${ }^{1}$

\section{Resumo}

A ética como reflexão filosófica fundamental no sentido de investigar, explicar, esclarecer uma determinada realidade humana, a realidade moral, elaborando conceitos, teorias. O lugar da ética no pensamento de Marx e Engels e na tradição marxista: crítica às teorias e práticas religiosas e ao modo de produção capitalista, tendo como pilares: a concepção de homem como ser concreto, social e histórico, a ontologia imanentista, a visão materialista da história, as determinações e relações sociais e econômicas determinadas, a sociedade dividida em classes antagônicas. As perspectivas políticas e educacionais de intervenção e transformação do estado atual de coisas.

Palavras-chave: Marxismo; Ética; Educação.

\section{Resumen}

La ética como reflexión filosófica fundamental en el sentido de investigar, explicar, esclarecer una determinada realidad humana, la realidad moral, elaborando conceptos, teorías. El lugar de la ética en el pensamiento de Marx y Engels y en la tradición marxista: crítica a las teorías y prácticas religiosas y al modo de producción capitalista, teniendo como pilares: la concepción de hombre como ser concreto, social e histórico, la ontología imanentista, la visión materialista de la historia, las determinaciones y relaciones sociales y económicas determinadas, la sociedad dividida en clases antagónicas. Las perspectivas políticas y educativas de intervención y transformación del estado actual de cosas.

Palabras claves: Marxismo; Ética; Educación.

${ }^{1}$ Doutor em Educação, professor do Centro de Ciências Humanas e da Educação, campus Jacarezinho, Universidade Estadual do Norte do Paraná. 


\section{Introdução}

o longo da história do pensamento ocidental, dentre as tantas
preocupações de investigar e dar respostas aos diversos problemas
que se referem ao ser, pensar e agir humano, situa-se a reflexão de natureza ética. A ética se constituiu como uma reflexão filosófica de um comportamento humano específico, o comportamento moral, que comumente é sintetizado pelas ações humanas livre, consciente, responsável.

Tais questões foram refletidas por tantos pensadores, sistematizadas em teorias éticas, muitas vezes expressas em grandes tratados éticos, que influenciam até hoje o pensamento e práticas humanas. Dentre tais pensadores, citamos Platão, Aristóteles, Agostinho, Tomás de Aquino, Descartes, Spinoza, Hume, Kant, Kierkegaard, Nietzsche, Stuart Mill, Max Weber, Freud, Foucault.

Assim, partimos da constatação de que a ética é uma questão presente na história do pensamento filosófico, que um grande número de pensadores e escolas filosóficas fizeram reflexões e produziram teorias éticas, que podem ser sintetizadas em duas grandes correntes teóricas, as éticas teleológicas e éticas deontológicas. As éticas teleológicas atribuem a função de critério supremo ao fim último para o qual se dirige o homem em suas ações, e estão presente no hedonismo, no utilitarismo, no eudaimonismo, nas éticas dos valores, por exemplo. As éticas deontológicas atribuem o papel de critério supremo às leis e aos deveres, como o estoicismo, o formalismo kantiano, por exemplo.

Diante desta constatação histórica, a pergunta, a questão, o problema posto por nós é: qual o lugar da ética em Marx e Engels e no marxismo, ou ainda, há fundamentos éticos no pensamento de Marx e Engels e no pensamento marxista? Se há, quais são estes fundamentos, qual o seu lugar na obra de Marx e Engels? No desafio de responder tal questão, fomos investigar as fontes do pensamento marxista, ou seja, aos textos de Marx e Engels. E ainda, na tradição marxista, quais autores fazem reflexão sobre a questão da ética. 
A primeira constatação é que Marx e Engels não produziram um tratado específico sobre ética, assim como não produziram um tratado específico sobre educação, sobre estética. Diante da dificuldade de uma análise profunda da vasta produção teórica de Marx e Engels, escolhemos e decidimos investigar alguns dos seus primeiros escritos, destacando entre estes os Manuscritos Econômico-Filosóficos, a Ideologia Alemã, a Sagrada Família.

No entanto, mesmo sem podermos analisar exaustivamente todos os textos de Marx e Engels, fomos levados a considerar, no núcleo da tradição marxista, a preocupação ética no pensamento de Marx e Engels. E descobrimos que, ao longo da tradição do pensamento marxista, muitos pensadores se dispuseram a discutir e produziram textos sobre ética. Dentre estes, citamos Lenin, Agnes Heller, Adolfo Sánchez Vásquez, Henri Lefebvre, Sérgio Lessa, Dermeval Saviani, Mihailo Markovic, István Mészaros. Outros autores, como Anton Shiskhin organizaram antologias de textos sobre ética e marxismo.

Ao longo da leitura dos textos de Marx e Engels e dos pensadores marxistas acima citados, chegamos à compreensão que a reflexão ética está presente no pensamento de Marx e Engels e na tradição marxista e que tal reflexão tem duas dimensões fundamentais: primeiro, a crítica às teorias éticas de fundamentação especulativa, idealista, utilitarista, religiosa, que foram elaboradas ao longo da história ocidental, como por exemplo, do hedonismo, do estoicismo, a ética religiosa, dos materialistas franceses, do formalismo kantiano, do idealismo de Hegel, do materialismo mecanicista de Feuerbach, do utilitarismo de Bentham; e segundo, a crítica ao modo de produção capitalista e sua maneira de conceber, pensar, agir, organizar as relações homem-natureza-sociedade.

\section{Os pilares da ética marxista}

A ética marxista se fundamenta na concepção de homem como ser concreto, social e histórico, em uma ontologia imanentista, na visão materialista da história, nas determinações da existência social dos homens sob relações sociais e econômicas determinadas, em uma sociedade dividida em classes 
antagônicas. A afirmação fundante da ética marxista são as condições materiais da existência humana.

A primeira condição de toda a história humana é, naturalmente, a existência de seres humanos vivos. A primeira situação a constatar é, portanto, a constituição corporal desses indivíduos e as relações que ela gera entre eles e o restante da natureza. [...] Pode-se distinguir os homens dos animais pela consciência, pela religião e por tudo o que se queira. Mas eles próprios começam a se distinguir dos animais logo que começam a produzir seus meios de existência, e esse passo à frente è a própria consequência de sua organização corporal (MARX; ENGELS, 2002, p. 10-11, grifo do autor).

Esta premissa, de ordem conceitual e história, fundamenta a interpretação de que:

Indivíduos determinados com atividade produtiva segundo um modo determinado entram em relações sociais e políticas determinadas. Em cada caso isolado, a observação empírica deve mostrar nos fatos, e sem nenhuma especulação nem mistificação, a ligação entre a estrutura social e política e a produção. [...] A produção das ideias, das representações e da consciência está, a princípio, direta e intimamente ligada à atividade material e ao comércio material dos homens. [...] São os homens que produzem suas representações, suas ideias etc., mas os homens reais, atuantes, tais como são condicionados por um determinado desenvolvimento de suas forças produtivas e das relações que a elas correspondem, inclusive as mais amplas formas que estas podem tomar. A consciência nunca pode ser mais que o ser consciente; e o ser dos homens é o seu processo de vida real (MARX; ENGELS, 2002, p. 18-19).

Assim, é a existência social dos homens que determina sua consciência, mas são os homens mesmos que transformam as circunstâncias. Daí a necessidade e possibilidade da intervenção e transformação da realidade e a 
perspectiva da emancipação humana universal. Por isso, a ética marxista não parte de conceitos abstratos, especulativos, mas das condições materiais de vida dos indivíduos humanos, ou seja, os conceitos éticos, filosóficos como a liberdade, a consciência, a responsabilidade humana, a emancipação só podem ser entendidos pela compreensão da base material social e histórica na qual surgem.

Portanto, a ética, do ponto de vista marxista, é uma investigação crítica, racional, imanente do processo histórico-social de produção e reprodução das ações humanas, na sua totalidade, no sentido de descobrir, elucidar os fundamentos materiais, sociais e históricos que condicionam e determinam suas ações humanas concretas, efetivas. Mesmo se a especificidade da ética marxista é também explicar o comportamento humano efetivo, e não se reduzir a uma perspectiva normativa, prescritiva, ela não é uma pura descrição das ações humanas, mas sua análise apresenta uma perspectiva de superação de toda teoria e prática que produzem e se sustentam pela opressão e pela exploração humana, especificamente da exploração do trabalho.

Se a especificidade da ética é "explicar, esclarecer ou investigar uma determinada realidade, a realidade moral, elaborando os conceitos correspondentes" (SÁNCHEZ VÁZQUEZ, 1998, p. 10), podemos reconhecer nas diversas teorias éticas elaboradas ao longo da história, os seus desdobramentos práticos, no sentido de influenciar, condicionar e determinar comportamentos humanos efetivos.

Por estar intimamente associada à análise da base econômica da sociedade e ocupar-se da totalidade das ações humanas é que a ética marxista não está em contradição com a sua análise crítica, com a investigação científica da realidade social. É na análise científica da sociedade que o marxismo expressa sua indignação, produz sua denúncia e empreende profundas críticas em relação às condições desumanas da classe trabalhadora, da exploração do trabalho.

Marx e Engels, no conjunto de seus escritos, fazem análises críticas da sociedade, repletas de desejo de transformação que, na nossa compreensão, caracterizam sua vitalidade e potencialidade sensibilizatória e revolucionária, 
ou seja, a possibilidade de "superação do estado atual de coisas" (MARX; ENGELS, 2002, p. 32) e da construção de um novo modo de produção, de novas relações sociais, de uma nova sociedade, "da emancipação humana universal” (MARX, 2004, p. 89). Assim, conhecer, ter ciência do real não está em contradição com a utopia, não idealista, metafísica, voluntarista, mas utopia ativa das possibilidades emancipatórias.

Ao lado da crítica, do desejo de transformação da sociedade capitalista, Marx e Engels afirmam de maneira contundente em sua filosofia e ação política que são os homens que transformam as circunstâncias materiais e históricas. Mas, quem seria esse homem? Eles encontram no trabalhador o homem concreto, histórico, social, aquele que vive e sofre toda forma de alienação, opressão e exploração. É este homem que, na sua efetiva condição de desumanização, tem a missão histórica de ser sujeito da auto-emancipação e da emancipação humana universal.

A ética marxista é uma ética de classe, forjada sob o ponto de vista da classe trabalhadora. A transformação do homem e da sociedade não se efetivará como aspiração e sonho sem base concreta, mas como possibilidade histórica real no sentido de avançar para além das determinações e condicionamentos do modo de produção capitalista, mediante concepções teóricas e ações concretas específicas como a educação revolucionária da classe trabalhadora.

Outro pilar no qual se funda a ética no marxismo é a história, que se faz dialeticamente, nas suas contradições, produzida pelos homens, condicionada pelas circunstâncias. O modo de produção capitalista também é uma produção histórica, daí, não ser natural nem eterno. É no seu próprio desenvolvimento que são criadas as condições materiais de sua superação e o surgimento de uma nova sociedade, de novos modos e relações de produção. A história é a atividade dos homens que buscam seus próprios fins, ou seja, a história em si não tem nenhum significado senão aquele que os homens, em seus vários estágios de desenvolvimento, lhe conferem.

Uma ética crítica, de classe, de base histórica, de perspectiva transformadora está intimamente ligada à educação omnilateral, como 
produção de homens conscientes e livres, capazes de conhecer, compreender e dominar o processo de produção material e espiritual e poder se apropriar dos bens produzidos. A dimensão ética da educação marxista propõe, mediante a educação, união e organização da classe trabalhadora, sobre a base sócio-econômico-cultural do desenvolvimento social, uma educação que possibilite à classe trabalhadora ter consciência de sua situação efetiva de alienação e exploração, ter conhecimento crítico dos mecanismos do modo de produção dominante e agir sobre as condições histórico-sociais determinadas, como possibilidade de exercer sua missão histórica transformadora.

Portanto, são estes os pilares que consideramos fundamentais para determinar o lugar da ética no pensamento marxista, presentes nos textos de Marx e Engels e da tradição marxista. Tais pilares, fundamentos poderiam ser sintetizadas nas palavras de Lenin (SHISKHIN, 1966, p. 222): "É ético o que serve para destruir a velha sociedade exploradora, para unir os trabalhadores em classe, produtora da nova sociedade". Se consideramos que são os homens que produzem, sob determinadas condições objetivamente dadas, a realidade, os complexos valorativos que tais homens erigem e constituem são igualmente frutos de suas aspirações, perspectivas teóricas e práticas.

Daí que, uma análise ética, nesta perspectiva, não se restringe a abstrações, imaginações e, portanto, a reflexão ética produz teorias, conceitos, mas parte de ações concretas, da "práxis como categoria central da filosofia que se concebe ela mesma não só como interpretação do mundo, mas também como guia de sua transformação" (SÁNCHEZ VÁZQUEZ, 1977, p. 5).

A ética marxista parte da compreensão da realidade na sua dinâmica, contradições e interesses sociais, econômicos. Parte-se da constatação que o modo de produção capitalista, pela sua lógica interna de exploração e por suas implicações e mazelas históricas provoca a desumanização do homem e da sociedade, como a fome, as guerras, as legiões de refugiados, a exploração do trabalho, a produção destrutiva, a exclusão de grande parte dos seres humanos do processo de produção e apropriação das condições materiais fundamentais de existência. 
Marx e Engels: crítica às éticas de fundamentação religiosa

Além da crítica às práticas e às justificativas teóricas do modo de produção capitalista, o marxismo também analisa criticamente as teorias éticas de fundamentação idealista, metafísica, religiosa. A base de todo este debate está na ontologia da imanência marxista, ou seja, contraposta à ontologia transcendental. É o que podemos perceber nos textos, como na Introdução à Crítica da Filosofia do Direito de Hegel, em O Comunismo de "O Observador Renano", na Circular contra Kriege, onde Marx e Engels investigam a relação entre religião e ética, como orientadoras de práticas morais.

As questões fundamentais desta crítica são: interferência da religião no processo de construção e desenvolvimento histórico material e espiritual do ser humano; a consideração da religião como um dos esteios em que se apóia a ordem social e política dominante, isto é, sua relação com os poderes econômicos e políticos estabelecidos; as causas históricas que explicam as razões pelas quais as condições e relações sociais tornam a religião indispensável à existência humana; a influência social da religião e a sua relação com a classe trabalhadora; a prática moral de natureza religiosa como expressão do individualismo; a crítica à ineficácia do discurso cristão do amor, da fraternidade universal.

Para tratarmos destas questões, do ponto de vista ético, nos fundamentamos na ontologia marxiana que tem como questão central a discussão entre transcendência e imanência, do ser humano, do mundo. De fato, a raiz de toda definição filosófica da religião encontra-se na afirmação de um ser transcendente criador do mundo, do qual o homem depende e ao qual se dirige. Nesta perspectiva, o conjunto das relações humanas é marcado pela dupla direção da imanência-transcendência, o que MÉSZÁROS (2006, p. 150) chama de "dualismo ético".

Nesta relação prevalecem as fontes e princípios provenientes da revelação divina, portanto, transcendentes e à margem da história. Neste sentido amplo, podemos entender por religião a fé ou a crença na existência de forças sobrenaturais ou num ser transcendente e sobre-humano, todopoderoso, com o qual o homem está em relação ou está religado. 
Do ponto de vista das relações entre o homem e a divindade, a religião se caracteriza: pelo sentimento de dependência do homem com respeito a Deus; pela garantia de salvação dos males terrenos que a religião oferece ao homem no outro mundo. Esta caracterização aplicada, sobretudo, ao cristianismo significa: a afirmação de Deus como verdadeiro sujeito e a conseqüente negação da autonomia do homem; a transposição da verdadeira libertação do homem para um mundo transcendente, ultraterreno, que somente se pode alcançar depois da morte. (SÁNCHEZ VÁZQUEZ 1998, p. 70).

Neste sentido, é preciso considerar que a religião inclui certa forma de regulamentação, de comportamentos, das relações entre os homens, ou seja, certa moral, onde os mandamentos divinos são, também, preceitos ou imperativos morais e a religião se apresenta como uma garantia do fundamento absoluto divino dos valores morais, assim como da sua realização no mundo. Assim, pode-se dizer que, sem religião não há moral. Nas palavras comumente citadas do romancista russo Dostoievski, se expressa de forma sintética esta posição: "Se Deus não existisse, tudo seria permitido". Não haveria, pois, uma moral autônoma que tivesse seu fundamento no homem: poder-se-ia afirmar somente a moral que tivesse o seu centro ou a sua fonte em Deus.

Assim a dignidade humana é concebida como negação da natureza humana, inspirada pelo dever (associada a um sentimento de gratidão etc) em relação ao ser a quem o homem deve sua própria existência [...] e o que existe pela graça de outro ser (o que eu lhe devo) não é liberdade, mas negação dela. (MÉSZÁROS, 2006, p. 150-151, grifos do autor).

Este posicionamento está apoiado na formulação ontológica marxista da relação específica homem-natureza e, portanto, o homem não pode ser identificado com alguma coisa abstratamente espiritual, com diz MARX (2004, p. 113): “Um ser se considera primeiramente como independente tão logo se sustente sobre os próprios pés, e só se sustenta primeiramente sobre 
os próprios pés tão logo deva a sua existência a si mesmo". Neste sentido, mesmo não tendo elaborado um texto específico sobre a religião, Marx a tratou de forma crítica, como um reflexo ou corolário de outros problemas, principalmente em relação à questão da alienação política e econômica, pois “o estranhamento econômico é o da vida efetiva" (MARX, 2004, p. 106).

Dentre as críticas à ética de fundamento religioso, Marx e Engels se referem especificamente do cristianismo, devido a sua influência social, o seu caráter mistificador, de ocultação da exploração humana. Ao invés da atitude de denúncia e proposta de superação da exploração, a religião apela para o além-transcendental para proclamar a resignificação e a conformidade do presente. Assim, a paciência, a aceitação, a humildade, diante do sofrimento presente transforma-se em virtude e na mediação necessária para a salvação futura.

No texto O comunismo de "O Observador Renano", Marx denuncia que “os princípios sociais do cristianismo pregam a necessidade de uma classe dominante e outra oprimida e para esta última só tem o desejo piedoso de que a primeira seja generosa” (MARX; ENGELS, 1976, p. 95). A crítica consiste, então, em que tal atitude reafirma o antagonismo de classes e que a justificação de tais fundamentos é pautada em um dualismo ético, isto é, a transferência para um plano supostamente superior, idealizado arbitrariamente o que poderia ser justificado no plano histórico.

A religião é uma das formas de opressão espiritual que pesa em toda a parte sobre as massas populares, esmagada pelo seu perpétuo trabalho para outros, pela miséria e pelo isolamento. A impotência das classes exploradas na luta contra os exploradores também gera tão inevitavelmente a fé em uma vida melhor além-túmulo, como a impotência dos selvagens na luta contra a natureza gera a fé em deuses, diabos, milagres, etc. Àquele que toda a vida trabalha e passa miséria a religião ensina a humildade e a paciência na vida terrena com a esperança da recompensa celeste. E àqueles que vivem do trabalho alheio a religião ensina a beneficência na vida terrena, propondo-lhes uma justificação muito barata para toda sua existência de exploradores 
e vendendo-lhes a preços módicos bilhetes para a felicidade celestial. A religião é o ópio do povo. A religião é uma espécie de má aguardente espiritual na qual os escravos do capital afogam a sua imagem humana, as suas reivindicações de uma vida medianamente digna do humano. (LÉNINE, 1984a, p. 291-292).

Enfim, a crítica à ética de natureza religiosa está em que seu caráter idealista e seu conteúdo individualista, espiritualista, intimista, servem para encobrir, camuflar os interesses materiais que mantém o status quo das classes economicamente privilegiadas e politicamente dominantes. A religião tem uma função social, é uma superestrutura funcional com uma base material, mas não de transformação social. A religião é um projeto humano, porém, mistificado. A produção religiosa não só normalmente reflete e reproduz a estrutura socioeconômica dominante como a legitima, a consolida e a perpetua. Para MARX (2004, p. 106) “o estranhamento religioso enquanto tal se manifesta na região da consciência, do interior humano, mas o estranhamento econômico é a da vida efetiva. Sua superação abrange, por isso, ambos os lados".

Ainda sobre a crítica ao idealismo ético de fundamentação religiosa, não poderíamos deixar de citar a crítica de Marx à ineficácia do ideal do amor, no texto intitulado "Circular contra Kriege", um violento panfleto contra o alemão Hermann Kriege, que trabalhava incansavelmente para difundir o comunismo utópico nos Estados Unidos da América. Kriege fixa os objetivos da luta comunista nestes termos:

Fazer uma verdade da religião do amor e uma realidade da comunidade dos habitantes da bem-aventurada morada esperada há tanto tempo [...] Nós pedimos, em nome desta religião do amor, que se sacie quem tem fome, que se dê de beber a quem tem sede e que se vista que está nu [...].

Marx, de maneira sarcástica, retruca: Pedido feito desde há 1800 anos até à náusea e sem o mínimo resultado (MARX; ENGELS, 1976, p. 389-390). 
A polêmica contra Kriege torna-se, também, uma violenta crítica à ética de natureza idealista, religiosa, de princípios a-históricos, metafísicos.

\section{Crítica e superação da ética capitalista}

Defendemos a tese de que a ética marxista faz a crítica da totalidade das ações e relações que sustentam o estado de opressão e exploração humana, especificamente a exploração do trabalho. Porém, junto à crítica e indignação, há a perspectiva e proposta de "superação do estado atual de coisas" (MARX; ENGELS, 2002, p. 32) e a construção da "emancipação humana universal" (MARX, 2004, p. 89).

Portanto, a ética marxista é, ao mesmo tempo, crítica e propositiva. Algumas questões são fundamentais para se compreender a proposta ética marxista: é na busca do real que o marxismo fundamenta sua ética; a ética marxista não se funda numa exigência subjetiva, mas na dialeticidade histórica, contraditória, ou seja, todo comportamento humano é intrínseco à totalidade dos processos da vida social configurada historicamente; a identificação da classe trabalhadora não como um ser moral ou eticamente superior, mas aquela classe que, na sua condição desumanizada, tem a missão histórica da auto-emancipação e da emancipação humana universal.

O marxismo se recusa a assentar valores fora do real e procura, portanto, na busca do real os fundamentos éticos. Quer dizer que tais juízos não são puramente descritivos, nem normativos, prescritivos, no sentido de dever, mas prospectivos, isto é, faz parte do mundo do possível e do necessário, capaz de superar tanto o cinismo capitalista, a resignação religiosa, quanto qualquer forma de idealismo.

Em Marx e Engels não há uma indiferença em relação ao comportamento moral dos homens, bem que está clara a opção que fizeram em transformar as raízes sociais que reproduzem e tornam imperativa a adesão a certos valores. Por isso, o marxismo se opõe a qualquer análise moralista em relação ao modo de produção capitalista, mas quer demonstrar suas contradições, assim como de apontar sua superação e produção de novas relações sociais. 
Os comunistas não pregam nenhuma moral genérica [...]. Eles não propõem aos homens os imperativos morais: amai-vos uns aos outros, não sejais egoístas etc; ao contrário, eles sabem perfeitamente que em determinadas situações tanto o egoísmo quanto o altruísmo são formas necessárias para a afirmação dos indivíduos. (MARX; ENGELS, 1976a, p. 17).

Por isso, a ética marxista não é uma abordagem moralizante dos efeitos desumanizadores do modo de produção capitalista, mas parte da análise crítica do estado atual das coisas, um mundo configurado sob as bases do modo de produção capitalista, que utiliza todas as suas forças para manter e reafirmar seu domínio. É sobre a paradoxal lógica do crescimento produtivo e a concentração das riquezas nas mãos de poucos, a produção de grandes catástrofes humanas, de uma forma de organização sócio-econômico-cultural que impede que os bens materiais produzidos historicamente sejam apropriados por todos os seres humanos, que se dá a crítica marxista e o seu pressuposto ético: a emancipação humana, possibilitada no desenvolvimento histórico, com a intensificação de tantos movimentos de resistências, de enfrentamentos, de perspectivas novas no modo de pensar e organizar a sociedade.

O pensamento ético marxista supõe um processo revolucionário na construção de uma nova forma de sociedade, a partir de novas relações econômicas, sociais, políticas, culturais, educacionais, construídas de forma consciente, livre e responsável pela classe trabalhadora, antagônica à ética capitalista.

Fez proliferar o egoísmo, e não a fraternidade, como o sentimento mais generalizado ao longo de todo o mundo. Quando um continente como o africano se dessangra, a vida nos países capitalistas centrais segue seu curso normal, os mercados de ações não se alteram, não se instaura um alarme geral, a indignação não se apossa das pessoas, para gerar atitudes concretas de apoio. A solidariedade, o humanismo, a cooperação 
desinteressada, os valores morais são devorados pela sanha do consumo, pelo egoísmo narcisista, pela busca de soluções individuais de salvação e de proteção diante da insegurança geral. (SADER, 2001, p. 129).

O que defendemos aqui é que, junto à crítica do modo de produção capitalista, fundado na acumulação do capital, na exploração do trabalho, na propriedade privada dos meios de produção, em detrimento das questões efetivas da humanidade, incapaz de ser uma forma humanizada de organização sócio-econômico-cultural do mundo, há uma ética alternativa de base marxista.

A maioria esmagadora da humanidade - mais gente do que nunca - vive de seu próprio trabalho, e não da exploração do trabalho alheio. Portanto, não são objetivamente dependentes da exploração que o capital opera sobre a força de trabalho. Ao contrário, são vítimas desse sistema. O que faz da questão ideológica, cultural e política da luta por uma sociedade humanista, solidária, um tema central de elaboração de propostas e alternativas de formas de vida e de coesão dessa grande maioria de trabalhadores, o que só pode se dar com base em valores morais e em formas de produção superiores ao capitalismo. (SADER, 2001, p. 129).

Afirmamos ainda que, numa visão de totalidade, as formas de organização sócio-econômico-cultural são acompanhadas de comportamentos morais. Numa visão dialética da história percebemos uma sucessão de comportamentos que correspondem às diferentes sociedades que se sucedem historicamente. Daí que na construção histórica da forma socialista de organização social há também um desenvolvimento moral, isto é, um comportamento superior à do modo de produção capitalista.

É evidente que se comparamos uma sociedade com outra anterior podemos objetivamente estabelecer uma relação entre as suas morais respectivas e considerar que uma moral é mais avançada, mais elevada 
ou mais rica do que a de outra sociedade [...] Existe, pois, um progresso moral que não se verifica, como vemos, à margem das mudanças radicais de caráter social. Queremos dizer que o progresso moral não se pode separar da passagem de uma sociedade para outra, isto é, do movimento histórico pelo qual se ascende de uma formação econômicosocial, que exauriu suas possibilidades de desenvolvimento, para outra superior. (SÁNCHEZ VÁZQUEZ, 1998, p. 39-40).

O que defendemos ainda é que o comportamento moral dos homens não se dá independentemente do processo de desenvolvimento históricosocial, apesar de que o primeiro não se reduz ao segundo, nem este àquele. $\mathrm{O}$ que define o desenvolvimento histórico-social é a totalidade das atividades materiais, sociais e espirituais do homem, o nível de desenvolvimento das forças produtivas.

Podemos falar, portanto, em progresso histórico no terreno da produção material, da organização social e da cultura. Não se trata de três linhas de progresso independentes, mas de três formas de progresso que se relacionam e se condicionam mutuamente, pois o sujeito do progresso nestas três direções é sempre o mesmo: o homem social. (SÁNCHEZ VÁZQUEZ, 1998, p. 41-42).

Neste sentido, só podemos falar de progresso histórico se a este acompanhar um progresso moral. No modo de produção capitalista isto não ocorre, pois não há correspondência entre o desenvolvimento técnicocientífico e sua apropriação material, pois numa mesma sociedade nem todos os indivíduos participam da produção e apropriação dos bens produzidos. Assim, o progresso histórico realiza-se mediante a exploração, a opressão nas relações sociais. Por isso, é impossível para o modo de produção capitalista criar as condições de adequação entre progresso histórico-social e progresso moral.

A formação do capitalismo e a conseqüente acumulação primitiva do capital - processo histórico progressista - realiza-se através dos 
sofrimentos e dos crimes mais espantosos. De modo análogo, a introdução da técnica mecanizada - fato histórico progressista acarreta a degradação moral do operário. (SÁNCHEZ VÁZQUEZ, 1998, p. 42-43).

Esta relação entre desenvolvimento social e moral já foi analisado por Engels, quando defendeu que em cada época histórica impera uma moral particular. Assim aconteceu na comunidade primitiva, na sociedade escravista, no feudalismo. A moral burguesa é a que predomina na sociedade capitalista. Porém, na sociedade capitalista moderna, além da predominância da moral burguesa, mantêm-se ainda muitos costumes da tradição feudal, herança do passado, como há a incorporação de uma moral da classe trabalhadora, a do futuro.

Assim, verificando que as três classes que constituem a sociedade moderna, que são a aristocracia feudal, a burguesia e o proletariado, possuem cada uma a sua moral particular, teremos, necessariamente, de concluir, que os homens, consciente ou inconscientemente, fazem derivar suas ideias morais, em última análise, das condições práticas em que se baseia a sua situação de classe, ou seja, das condições econômicas em que produzem e trocam os seus produtos. (ENGELS, 1976, p. 78-79).

O marxismo defende, como moral do futuro, a moral da classe trabalhadora, pois esta classe, pela sua consciência e ação, pode abolir a alienação humana, pois é a classe a vivê-la e a sofrê-la na sua forma mais perversa. Só a classe trabalhadora pode libertar a sociedade e o homem libertando-se a si próprio, criando novos valores. Mas a classe trabalhadora não é identificada como um ser eticamente superior, mas aquela classe social que, elevada à desumanização mais extrema, tem uma missão histórica.

O proletariado pode e deve libertar-se a si mesmo. Ora, ele não se pode libertar sem abolir as suas próprias condições de vida. Não pode as suas próprias condições de vida sem abolir todas as condições de vida 
inumanas da sociedade atual, o que resume a sua própria situação [...] Não se trata de saber que objetivo este ou aquele proletário, ou até o proletariado inteiro, tem momentaneamente. Trata-se de saber o que é o proletariado e o que ele será historicamente obrigado a fazer de acordo com este ser (MARX; ENGELS, s/d, p. 54-55, grifos do autor).

É esta finalidade histórica do possível e do necessário que a classe trabalhadora se desperta para a luta constante, postulando assim a autoemancipação e a emancipação da sociedade como um fim valioso. Portanto, não é pela moral que se poderá chegar à conquista da auto-emancipação, mas ela se constitui numa grande fonte de façanhas na sua construção.

Para se chegar à conquista de uma moral realmente humana, subtraída a todos os antagonismos de classes ou mesmo à sua recordação, teremos, antes, de alcançar um tipo de sociedade na qual não somente se tenha abolido o antagonismo das classes, mas também tenha sido esse antagonismo, além de abolido, esquecido e afastado das práticas da vida. (ENGELS, 1976, p. 79).

E, se a história é um movimento de superação, então é preciso superar o egoísmo e o individualismo capitalista, onde reina a hostilidade, a indiferença dos homens entre si, onde há a exploração humana por parte da classe dominante sobre os trabalhadores. A superação deste estado, como necessidade histórica, se dará no movimento revolucionário de fundamentação socialista, com a prática de novas relações sociais e produtivas.

Então cessa a luta pela existência individual [...] As condições de vida que cercam ao homem e que até agora o dominavam passam, a partir desse instante, sob seu domínio e seu mando, e o homem, ao converterse em dono e senhor de suas próprias relações sociais, se converte, pela primeira vez, em senhor consciente e efetivo da natureza. (ENGELS, 1976, p. 265-266). 
O fundamento da ética marxista está intimamente imbricado com a visão sócio-econômico-cultural, na análise da relação homem-naturezasociedade historicamente constituída. Daí a crítica e denúncia de toda forma de alienação, reificação do homem e desumanização do homem e da sociedade. Toda esta indignação, partindo da concreta situação de exploração da classe trabalhadora, mas conclamada à uma práxis, consciente e transformadora de uma realidade social inumana, constitui a crítica ética mais efetiva à sociedade capitalista. Diz Lenin (SHISKHIN 1966, p. 219-220):

Existe uma ética comunista? É evidente que sim [...]. Mas repudiamos toda a moral derivada de conceitos não-humanos e não-fundamentados em classes [...]. Dizemos que nossa moral é totalmente subordinada aos interesses da luta de classes do proletariado [...]. Nossa moral serve ao objetivo de ajudar a sociedade humana a ascender a um nível mais elevado e a livrar-se da exploração do trabalho.

Em uma sociedade dividida em classes antagônicas, é pela luta que se estabelece sua manutenção ou transformação. O marxismo não é messiânico, ou seja, não fomenta esperanças de que se os homens aguardarem pacientemente a sociedade algum dia se tornará livre. Também não retrata em cores vivas uma nova sociedade, que é possível, sem a luta e o esforço de construí-la sobre princípios e ações sólidos. O que o marxismo mostra é o mecanismo real da transformação social, ou seja, é uma praxis social, "uma atividade prática revolucionária que implica na destruição de uma determinada ordem social, para instaurar ou criar uma nova estrutura social" (SÁNCHEZ VÁZQUEZ, 1977, p. 377).

Enfim, não pode haver um discurso ético significativo com base na premissa de que não há alternativa para o que está aí constituído, pois a ética se refere também à avaliação e justificativa de objetivos que os indivíduos e grupos sociais postulam implementar para a sua vida e sociedade. Nisto entendemos em que consiste a concepção dialética e revolucionária da ética socialista. 


\section{A relação entre ética, política e educação}

Entendemos que há possibilidades de construção da nova sociedade. Mas esta nova sociedade não é anunciada de forma mágica e fantástica, voluntarista, como milagre divino, nem por acaso, mas é construída historicamente pela união, educação, e organização da classe trabalhadora, sobre a base sócioeconômico-cultural do movimento do desenvolvimento social.

A dimensão ética e política da educação marxista supõem o conhecimento da situação efetiva e missão histórica da classe trabalhadora, de desmascaramento das contradições internas e das mazelas históricas do modo de produção capitalista, da superação da alienação, desumanização, coisificação, da superação da propriedade privada dos meios de produção e da exploração do trabalho. Isso é possível pelo desenvolvimento omnilateral da classe trabalhadora, pela construção de novas relações sociais, radicalmente humanizadas e de bases socialistas.

O novo, o ainda não totalmente efetivado, surge do velho. A sociedade nova é forjada a partir desta que está aí. Acontece que, sendo contraditória, a sociedade existente traz em seu bojo as forças do novo e as forças do velho em choque. Enquanto uma tem interesse em perpetuar a dominação, a outra tem interesse em superar e se libertar do modelo dominante. E tal libertação aponta para a justificação e criação de um novo tipo de sociedade. (SAVIANI, 2002, p. 226).

A dimensão ética e política da educação é um chamamento para a recuperação da vida humana, o homem como ser social, de crítica a toda forma de reduçao do ser humano a uma individualidade pobre, mutilada, não permitindo o desenvolvimento das suas capacidades criativas e muito menos o livre desenvolvimento de todos os individuos humanos. Uma educação omnilateral significa a atuação dos indivíduos sobre as condições históricosociais determinadas, no sentido de propiciar a possibilidade de uma totalidade de atividade e de uma totalidade de apropriação dos bens produzidos. Neste sentido, a fundamentação ética marxista consiste em 
identificar-se com a classe trabalhadora em sua educação, organização e luta contra a exploração e opressão capitalista.

Para vencer a resistência da classe dominante só há um meio: encontrar na própria sociedade que nos rodeia, educar e organizar para a luta, os elementos que possam - e, pela sua situação social, devam - formar a força capaz de varrer o velho e criar o novo (LÉNINE, 1984b, p. 95, grifos do autor).

Tratar da ética no marxismo é tão difícil quanto querer negar nele tal dimensão, pois compreendemos que nenhuma afirmação sobre o marxismo poderá ser considerada concluída. O marxismo se prova na ação, daí só podermos falar de ética mediante a ação efetiva dos indivíduos humanos, em constante movimento, nas suas determinações materiais, históricas. Daí ser a ética essa reflexão crítica e radical no sentido de analisar os diversos movimentos históricos, suas efetivas e possíveis transformações, como ação do homem sobre as circunstâncias históricas.

Portanto, a crítica ao modo de produção capitalista requer, para sua superação, uma efetiva proposta pedagógica interventiva e transformadora, um compromisso ético, político e social dos educadores, dos educandos, da escola. É aqui que entra a dimensão ética e política da educação, isto é, de não ajustamento, de não adaptação ao modo de produção capitalista, mas de ser uma mediação na formação de uma racionalidade consciente, interventiva, de fortalecer a resistência no desenvolvimento do processo social, nas várias dimensões humanas, especificamente a política, que significa agir sobre o mundo e compreender essa ação.

Quando afirmo que a educação é sempre um ato político, quero como isso frisar que a educação cumpre sempre uma função política. Mas é preciso não identificar essa função política com outra função que a educação cumpre, que é a técnica. Estas funções não se identificam, elas se distinguem. Mas, embora distinguíveis, são inseparáveis, ou 
seja: a função técnica é sempre subsumida por uma função política. (SAVIANI, 2002, p. 212).

Neste sentido, a educação cumpre a necessária missão de uma contundente crítica das concepções e práticas educacionais atreladas à lógica do capital, que tem no individualismo, no lucro, na mercantilização, na competição e na exploração do trabalho seus fundamentos. A educação capitalista não vai além da reprodução, legitimação e manutenção da ordem dominante vigente, incapaz de transcender os limites do capital. É neste contexto que surge a necessiade de pensar uma "educação para além do capital" (MÉSZÁROS, 2005).

Porém, pensar uma alternativa educacional que seja formulada do ponto de vista da emancipação humana universal, mesmo diante da força do capital é um desafio possível, pelo fato do capitalismo, mesmo com toda sua força condicionante, ser limitado em relação à sua imposição sobre a produção das idéias, das ações e práticas humanas. As idéias não são impostas e aceitas automaticamente; por isso, as idéias capitalistas como construções sócioeconômico-culturais históricas não são naturais, nem eternamente necessárias. É no interior do próprio desenvolvimento do modo de produção capitalista que, ao mesmo tempo há uma manutenção da ordem vigente e nascem as idéias superadoras e construtoras de uma nova realidade. É na articulação da totalidade social do ser e do existir humanos que se realiza a dimensão ética e política da educação.

O processo de produção de uma educação transformadora passa, antes de tudo, pelo debate entre uma teoria reflexivo-analítica, de esclarecimento racional, e uma prática consciente, possível, propositiva, aberta, possibilitando a todo ser humano ser sujeito capaz de compreender, se posicionar e intervir nos processos de produção da vida e da sociedade para produzir homens plenamente livres, desenvolvidos.

O homem se apropria da sua essência omnilateral de uma maneira omnilateral, portanto como um homem total. Cada uma das suas relações humanas com o mundo, ver, ouvir, cheirar, degustar, sentir, 
pensar, intuir, perceber, querer, ser ativo, amar, enfim todos os órgãos da sua individualidade, assim como os órgãos que são imediatamente em sua forma como órgãos comunitários, são no seu comportamento objetivo ou no seu comportamento para com o objeto a apropriação do mesmo, a apropriação da efetividade humana; seu comportamento para com o objeto é o acionamento da objetividade humana [...] eficiência humana e sofrimento humano, pois o sofrimento, humanamente apreendido, é a autofruição do ser humano (MARX, 2004, p. 108, grifos do autor).

Outra questão fundamental na construção de uma educação que seja transformadora é a convicção de que a história não é estática, é um movimento dinâmico, contraditório, que está sendo construída a cada dia por indivíduos que estão vivendo seu próprio momento histórico. Só assim é possível acreditar, possibilitar é fazer acontecer concretamente as mudanças, as transformações, "as necessárias aspirações emancipadoras" (MÉSZÁROS, 2005, p. 59, grifos do autor).

Assim, o ser humano não pode se entrincheirar, se refugiar numa cômoda vida individualista e indiferente em relação à construção dos destinos da humanidade. Ainda mais, é preciso reagir contra toda forma de imitação, reprodução ou simples aceitação do já determinado. A história está para ser construída, com a utilização da capacidade humana criadora, inovadora e transformadora.

É preciso superar a forma capitalista de pensar, organizar a sociedade e resgatar os ideais socialistas e sua concepção de homem, de sociedade, de natureza como condição necessária de possibilidade de levar cada homem a uma nova forma de produzir a vida e construir a nova sociedade, mais elevada e humanizada. Isso não se realiza a partir de propostas reformistas, mas somente "com uma reestruturação radical das nossas condições de existência há muito estabelecidas e, por conseguinte, de 'toda a nossa maneira de ser'" (MÉSZÁROS, 2005, p. 60, grifos do autor). Para isso, a fundamental contribuição da educação no processo de superação do estado atual de coisas. 
O papel da educação é soberano, tanto para a elaboração de estratégias apropriadas e adequadas pra mudar as condições objetivas de reprodução, como para a automudança consciente dos indivíduos chamados a concretizar a criação de uma ordem social metabólica radicalmente diferente. É isso que se quer dizer com a concebida ‘sociedade de produtores livremente associados'. Portanto, não é surpreendente que na concepção marxista a "efetiva transcendência da auto-alienação do trabalho" seja caracterizada com uma tarefa inevitavelmente educacional. (MÉSZÁROS, 2005, p. 65, grifos do autor).

Enfim, neste sentido, qualquer proposta nova, também no campo educacional, ético, político, se choca com discursos e práticas petrificadas, resignadas, que insistem em manter suas maneiras de pensar, organizar o processo social. Daí a necessidade da de atitudes que possam desafiar, reagir a toda tentativa unilateral de adaptação e servilismo aos interesses do mercado capitalista.

\section{Consideraçoes finais}

A ética marxista não é normativa, nem prescritiva. Sua base teórica e política é a história. À luz do desenvolvimento histórico, ela procura explicar porque em determinada época histórica predominam princípios e normas de comportamento e em virtude de que razão estas dão lugar a outros princípios. Marx e Engels não dizem nem fazem uma descrição de como será a história futura, apenas mostram o mecanismo efetivo de sua construção, feita pelos homens, conscientemente, na busca de seus objetivos.

A história é feita pelas ações humanas, é continuidade e ruptura. A humanidade não escolhe as circuntâncias e a base material sobre a qual constrói alternativas de seu desenvolvimento, mas pode agir sobre essa base e alterá-la. "Os homens fazem sua própria história, mas não a fazem como querem; não a fazem sob circunstâncias de sua escolha e sim sob aquelas com que se defrontam diretamente, legadas e transmitidas pelo passado" (MARX, 1974, p. 335). 
A história não é previsão, mas determinação que requer dos trabalhadores "que coloquem sob seu controle consciente as condições materiais de vida, condições que antes haviam sido abandonadas ao acaso, e que por isso adquiriram uma existência independente, contrapondo-se aos indivíduos" (MARX; ENGELS, 2002, p. 93). Isso significa que o marxismo tem sonho, utopias, do que é possível acontecer, uma vez abolida a exploração do homem pelo homem.

Ter conhecimento da realidade efetiva, ter consciência das possibilidades de sua superação, se utilizar dos meios adequados para esse intento se constituem exigências éticas necessárias na luta para superar o "estado atual de coisas" e construir a sociedade sobre novas bases. E todo esse movimento se constitui a praxis humana. A ética marxista é teórica e prática. Os fins a serem alcançados só podem ser estimados na relação com os meios necessários à sua realização histórica. É por isso que a ética marxista é crítica, educativa, propositiva, utópica.

\section{Referências}

ENGELS, Friedrich. Anti-Dühring. Rio de Janeiro: Paz e Terra, 1976.

LÉNINE, Vladimir Ilich. Obras escolhidas. 1. Moscovo: Progresso; Lisboa: Avante, 1984a.

. Obras escolbidas. 2. Moscovo: Progresso; Lisboa: Avante, 1984b.

MARX, Karl; ENGELS, Friedrich. A sagrada família. Portugal: Presença; Brasil: Martins Fontes, s/d. . Sobre a religião. Lisboa: Edições 70, 1976.

_. A ideologia alemã. Vol. II. Lisboa: Editorial Presença, 1976a.

_. A ideologia alemã. São Paulo: Martins Fontes, 2002.

MARX, Karl. O 18 Brumário de Luis Bonaparte. São Paulo: Abril Cultural, 1974. . Manuscritos econômico-filosóficos. São Paulo: Boitempo, 2004.

MÉSZÁROS, István. A educação para além do capital. São Paulo: Boitempo, 2005. A teoria da alienação em Marx. São Paulo: Boitempo, 2006.

SADER, Emir. Século XX: uma biografia não autorizada. São Paulo: Fundação Perseu Abramo, 2001. 
SÁNCHEZ VÁZQUEZ, Adolfo. Filosofia da práxis. Rio de Janeiro: Paz e Terra, 1977.

. Ética. Rio de Janeiro: Civilização Brasileira, 1998.

SAVIANI, Dermeval. Educaşão: do senso comum à consciência filosófica. Campinas: Autores Associados, 2002.

SHISKHIN, Anton. Ética. Buenos Aires: Cartago, 1966. 